\title{
NEW AND EXTENSIVE SECTIONS OF BOULDER-CLAY AT LIVERPOOL.
}

Sir,-That your readers, during the tourist season, may have an opportunity of seeing a series of the largest and most important sections they may ever meet with in their lives, I lose no time in directing their attention to the excavations for the new Canada Docks, near Bootle Station, Liverpool. There is a lower glacial clay (which is worked with the pick) underlying a greater or less thickness of non-glacial gravel and sand; but the great deposit exposed is the upper or brick clay (which is worked with the spade). Though I had previously seen boulders in this clay in different localities, I was not prepared to find such an array of large blocks more or less imbedded in the clay at different levels, and apparently in the spots where they had been dropped. The majority, so far as my observations extended, were greenstone, and numbers of them might be seen lying near to each other as if they had been picked up from the same spot (in the Lake District) by a mass of coast-ice, which floated them and laid them down without severing their family connexion. Many of the boulders were quite five feet in length, and in shape varied from round to sub-angular and angular. Most of them were intensely glaciated. I have to thank Mr. Morton, F.G.S., for directing my attention to the above sections.

\section{Machintosh.}

\section{LLANDOVERY ROCKS IN THE LAKE DISTRICT.}

Sir,-In reply to Mr. Aveline's last letter, I beg to state that the evidence relied on by me in drawing up the Table was obtained from the published statements of the authors whose names appear at the head of the column referred to (p. 156); and who, I believe, have not only obtained "fossil evidence" sufficient to warrant their speaking "confidently of their position," but have been able also to qualify this by " a careful stratigraphical survey of the rocks."

I am permitted also to state that Professors Harkness and Nicholson have recently discovered a group of fossils in these mudstones which, if fossil evidence is to be recognized as of any importance (and he must be a bold man who in the present state of our knowledge is prepared to cast this evidence entirely aside), make it almost impossible for these beds to be so high in the succession as Mr. Aveline would have us believe. Moreover, these fossils are specifically for the most part identical with those of the same genera found in Wales in Upper Bala and Llandovery rocks. The full particulars of this interesting and important discovery will be communicated by Professors Harkness and Nicholson to the British. Association at Glasgow; but I am allowed to state here that the result has been to prove "that the sequence from the Coniston Limestones to the mulstones is perfect, and that there is no unconformability, but that the mudstones must be regarded as the highest portion of the Bala series," or as the equivalents of the Lower Llandovery. 
Mr. Aveline's own evidence also tells completely against himself when he acknowledges that the mudstones are "the equivalents of the Tarannon shales of Wales, and the Coniston grits and flags equivalent to the Denbighshire grits and flags," since recent evidence is entirely opposed to the view, held by the members of the Geological Survey, and as published in their maps, that the Tarannon shales of Wales overlie the whole of the Llandovery rocks. In a paper which I read at the meeting of the British Association at Bristol last year, I brought forward evidence from numerous sections in North Wales and Shropshire to prove that the pale shales (marked Tarannon Shales on the Survey maps) and some overlying grits in Denbighshire held exactly the same position there stratigraphically as the Llandovery rocks did in South Wales; and the palæontological facts also were in accordance with this view. Since then further researches have been made, and much additional evidence obtained tending to confirm this view. I have no hesitation now in stating, on the strength of palæontological and stratigraphical evidence, that the Tarannon shales are nothing more than equivalents of portions of the Llandovery rocks, chiefly Lower Llandovery, and that the grits associated with and immediately overlying those pale shales in many parts in Denbighshire, and to the east of Corwen, and near Bala, are the equivalents of the Upper Llandovery and May Hill sandstones. Moreover, at these places there is not the slightest sign of an unconformity between the Bala beds and these overlying rocks. I have endeavoured to show in my previous papers that this area, like that of South Wales, probably remained submerged during Mid-Silurian changes, and I have only suggested the probability that areas in Cumberland might also have passed through similar changes without having been at the time raised above sealevel. I may be allowed to state, in defence of the value of palæon. tological evidence, that it is seldom found to lead one astray to the extent that lithological evidence seems to have done in the case of these Tarannon shales. It seems indeed strange also that a band of shales avowedly with no fauna at the time should have a distinctive colouring on the Survey map; when so many truly important series of far greater thickness, and containing numerous rich faunas, should be scarcely recognizable in one tint.

To Mr. Ward I need only say that the general tone of his letter, to say the least of it, is detrimental to the proper discussion of facts; and that the only argument employed by him, that of authority, is one to which I am not at all prepared to bow. My experience hitherto has taught me to rely rather upon the strength of facts than authority, and to value opinions in proportion as they seem to be supported by the facts.

\footnotetext{
Heriot House, Hendon,

Henry Hicks.
} August 8 th, 1876. 